\title{
PENGEMBANGAN MODEL PEMBELAJARAN MATEMATIKA STAIR (STUDY CONFIDENT IN PAIR) PADA MATERI PERBANDINGAN UNTUK SISWA KELAS VII SMP/MTs
}

\author{
Ihda Mawaddatul 'Aliyah' \\ ${ }^{1}$ Guru Matematika MTs Al-Ma'arif Bocek Karangploso Malang \\ Email: ${ }^{1}$ ihdaaliyah553@gmail.com
}

\begin{abstract}
Abstrak
Mata pelajaran matematika harus dapat memberikan kontribusi sesuai dengan kurikulum 2013 yaitu desain pembelajaran yang meningkatkan aktivitas peserta didik. Desain pembelajaran tersebut adalah model pembelajaran. Salah satu model pembelajaran yang dapat meningkatkan aktivitas peserta didik adalah model pembelajaran kooperatif. Dalam hal ini pengembang menggunakan dua tipe model kooperatif, yaitu numbered heads together dan think pair share yang dikolaborasikan sehingga menghasilkan model pembelajaran matematika STAIR (Study Confident in Pair) yang bertujuan untuk meningkatkan aktivitas peserta didik dalam proses pembelajaran. Pengembangan model tersebut menggunakan lima langkah yang diadaptasi dari model pengembangan Borg \& Gall yaitu: (1) penelitian dan pengumpulan data, (2) perencanaan, (3) pengembangan draft produk, (4) uji coba lapangan, dan (5) revisi akhir. Secara keseluruhan pengembangan model tersebut dinyatakan valid oleh ketiga validator yaitu: ahli pembelajaran dengan skor 3,34, ahli desain dan perancang pembelajaran dengan skor 3,36, praktisi dengan skor 3,50, dan hasil rata-rata skor ketiga validator sebesar 3,40 yang memenuhi kriteria kevalidan yang ditetapkan. Sedangkan hasil uji user, dinyatakan praktis dengan skor 3,44 dari pendidik dan skor 3,78 dari peserta didik dan rata-rata skor keduanya adalah 3,61. Dengan demikian, disimpulkan bahwa pengembangan model pembelajaran matematika STAIR (Study Confident in Pair) dinyatakan valid dan praktis sehingga dapat diterapkan dalam proses pembelajaran.
\end{abstract}

Kata Kunci: pengembangan, model pembelajaran matematika STAIR (Study Confident in Pair), materi perbandingan

\section{PENDAHULUAN}

Pendidikan mengalami dinamika yang semakin lama semakin berkembang dan berusaha untuk beradaptasi dengan gerak perkembangan serta mengarah pada kemajuan pendidikan yang semakin baik. Oleh sebab itu, dunia pendidikan juga memerlukan berbagai inovasi. Salah satu hal yang tidak dapat terlepas dari pendidikan adalah proses pembelajaran. Setiap proses pembelajaran yang dilaksanakan seharusnya dapat mencapai tujuan dari pembelajaran yang telah ditentukan dan disesuaikan dengan perkembangan kurikulum yang ada.

Desain pembelajaran yang diharapkan dalam kurikulum 2013 pada dasarnya adalah desain pembelajaran yang menarik, serta dapat meningkatkan aktivitas peserta didiknya. Desain pembelajaran tersebut adalah model pembelajaran. Salah satu model pembelajaran yang dapat meningkatkan aktivitas peserta didik adalah model pembelajaran kooperatif. Dalam hal ini pengembang menggunakan dua tipe model pembelajaran kooperatif, yaitu numbered heads together, dan think pair share yang dikolaborasikan sehingga menjadi model pembelajaran matematika STAIR (Study Confident in Pair).

Kombinasi tersebut bertujuan untuk menutupi kekurangan yang terjadi dalam penerapan model pembelajaran kooperatif sehingga dapat berpengaruh pada aktivitas dalam pembelajaran kelompok seperti terjadinya kekacauan di kelas dikarenakan bedanya pendapat antar peserta didik, adanya peserta didik yang tidak senang bila disuruh untuk bekerja sama, 
adanya pembagian tugas yang tidak sama antar peserta didik. Untuk itu, pengembang hanya menggunakan dua tipe model pembelajaran kooperatif yang dikombinasikan menjadi satu model baru.

Pengembang mengkombinasikan dua tipe model pembelajaran tersebut berdasarkan pada hasil penelitian yang telah dilakukan oleh Hermindina (2010:1) tentang penerapan kolaborasi model numbered heads together dengan two stay two stray yang telah berhasil dilakukan dengan tujuan untuk meningkatkan aktivitas dan hasil belajar kewirausahaan siswa, begitu juga penelitian pengembangan yang dilakukan oleh Sari (2013:1) tentang pengembangan model pembelajaran kooperatif STADTUS (kolaborasi STAD dengan Tutor Sebaya) dalam pembelajaran IPA, yang menghasilkan suatu pemaduan model pembelajaran kooperatif yang berlandaskan kerjasama tim dipimpin oleh tutor sebaya guna mencapai tujuan pembelajaran. Berdasarkan penelitian mereka, pengembang ingin melakukan penelitian tentang pengembangan model pembelajaran yang mengkombinasikan dua tipe model pembelajaran kooperatif.

Tujuan yang ingin dicapai dalam pengembangan ini adalah menghasilkan model pembelajaran baru sehingga dapat menutup kekurangan yang terjadi dalam proses pembelajaran agar setiap dalam pembelajaran peserta didik menjadi saling berinteraksi secara maksimal begitu juga dengan aktivitas mereka, sehingga perbedaan kecepatan dan kemampuan tiap-tiap individu peserta didik dapat diperkecil. Bagi peserta didik yang mempunyai kecepatan dan kemampuan yang kurang diharapkan dapat dibantu oleh temannya dalam satu kelompok yang mempunyai kemampuan lebih baik, sehingga peserta didik yang mempunyai kemampuan sedang dapat segera menyesuaikan dalam proses pemahaman materi.

Seels dan Richey (dalam Setyosari, 2015: 280) menyatakan bahwa pengembangan berarti proses menerjemahkan atau menjabarkan spesifikasi rancangan ke dalam bentuk fisik atau dengan ungkapan yang lain, pengembangan berarti proses menghasilkan bahan-bahan pembelajaran. Kemudian model pembelajaran ialah pola yang digunakan sebagai pedoman dalam merencanakan pembelajaran di kelas maupun tutorial (Suprijono, 2012:46). Plato (dalam Fathani, 2012:21) berpendapat bahwa matematika identik dengan filsafat untuk ahli pikir, walaupun mereka mengatakan matematika harus dipelajari untuk keperluan lain.

Dapat disimpulkan bahwa pengembangan model pembelajaran matematika adalah suatu proses menerapkan pengetahuan untuk memperbaiki atau menghasilkan suatu produk yang dapat diterapkan dalam proses pembelajaran sehingga memperoleh ilmu pengetahuan.

Anita Lie (dalam Suprijono, 2012:56) menyatakan bahwa model pembelajaran ini didasarkan pada falsafat homo homini socius yang menekankan bahwa manusia adalah makhluk sosial. Tanpa interaksi sosial, tidak mungkin ada kehidupan bersama. Dengan kata lain, kerjasama merupakan kebutuhan yang sangat penting artinya bagi kelangsungan hidup. Dukungan lain dari teori Vygotsky terhadap model pembelajaran kooperatif adalah arti penting belajar kelompok (Suprijono, 2012:56).

Dengan demikian, belajar dalam kooperatif berlangsung dengan interaksi antara anggota kelompok serta memberikan kesempatan bagi peserta didik untuk memperoleh dan memberi masukan kepada temannya.

Pada dasarnya, Numbered Heads Together (NHT) merupakan varian dari diskusi kelompok. Menurut Slavin (dalam Huda 2013:203), metode yang dikembangkan oleh Russ Frank ini cocok untuk memastikan akuntabilitas individu dalam diskusi kelompok. Tujuannya adalah memberikan kesempatan kepada peserta didik untuk saling berbagi gagasan, mempertimbangkan jawaban yang paling tepat sehingga dapat meningkatkan kerjasama peserta didik serta bisa diterapkan untuk semua mata pelajaran dan tingkatan kelas dengan cara memberikan nomor kepada peserta didik dan membetuknya menjadi kelompok kemudian memanggil nomor tesebut secara acak. 
Jadi, model pembelajaran Numbered Heads Together (NHT) adalah model pembelajaran dimana setiap peserta didik diberi nomor dan dibentuk kelompok kemudian secara acak pendidik memanggil nomor tersebut sehingga peserta didik dituntut untuk selalu siap dalam mengkomunikasikan hasil yang diperoleh.

Strategi Think Pair Share (TPS) atau berpikir berpasangan merupakan jenis pembelajaran kooperatif yang dirancang untuk mempengaruhi pola interaksi siswa yang dikembangkan oleh Frank Lyman di University of Maryland pada 1981 dan diadopsi oleh banyak penulis di bidang pembelajaran kooperatif pada tahun-tahun selanjutnya. Think Pair Share ini memperkenalkan gagasan tentang waktu 'tunggu atau berfikir' (wait or think time) pada elemen interaksi pembelajaran kooperatif yang saat ini menjadi salah satu faktor ampuh dalam meningkatkan respon siswa terhadap pertanyaan (Huda, 2013:206).

STAIR (Study Confident in Pair) dalam pengembangan model pembelajaran ini merupakan kombinasi dari dua tipe model pembelajaran kooperatif yaitu: numbered heads together dan think pair share yang dalam pembelajarannya memberikan kesempatan kepada peserta didik untuk belajar dalam kelompok serta membangun kerja sama dan komunikasi yang baik dalam kelompoknya, sehingga model tersebut diharapkan dapat meningkatkan aktivitasnya dalam pembelajaran. Dengan meningkatnya peran peserta didik sehingga prestasi yang dimilikinya juga meningkat khusunya juga dapat mewujukan sikap toleransi peserta didik dapat berdampak pada tujuan dari pendidikan, serta secara umum dapat tercapainya proses pembelajaran yang menyenangkan.

\section{METODE}

Model pembelajaran matematika STAIR (Study Confident in Pair) pada materi perbandingan untuk siswa kelas VII SMP/MTs ini dikembangkan dengan lima tahap model pengembangan yang diadaptasi dari model Borg \& Gall yaitu: (1) penelitian dan pengumpulan data, (2) perencanaan, (3) pengembangan draft produk, (4) uji coba lapangan, dan (5) revisi akhir.

Jenis data dari pengembangan ini terdiri dari dua macam yaitu data kualitatif: (a) jawaban dari responden (pendidik dan peserta didik) dalam angket respon. (b) komentar dan saran perbaikan dari validator pada lembar validasi. (c) penarikan kesimpulan oleh pengembang setelah melakukan analisis data, yaitu berupa valid atau tidak, praktis atau tidak hasil pengembangan model pembelajaran matematika STAIR (Study Confident in Pair), serta kuantitatif yaitu: (a) skor pada angket penilaian hasil pengembangan model pembelajaran pada ahli pembelajaran matematika. (b) skor pada angket penilaian hasil pengembangan model pembelajaran pada ahli desain dan perancang pembelajaran. (c) skor pada angket penilaian hasil pengembangan model pembelajaran pada praktisi. (d) skor rata-rata yang diperoleh dari hasil perhitungan analisis data. Teknik analisis data disesuaikan dengan data yang ada. Data kuantitatif diperoleh dari penghitungan skor pada angket validasi ahli dan praktisi, sedangkan data kualitatif berupa respon dari peserta didik dan pendidik serta kritik dan saran yang ditulis oleh ahli dan praktisi di lembar validasi.

Lokasi yang digunakan dalam penelitian ini yaitu MTs Al-Ma'arif Bocek Karangploso Malang yang melibatkan seorang pendidik matematika dan 20 orang siswa. Adapun prosedur pengembangan model pembelajaran matematika STAIR (Study Confident in Pair) ini dapat dilihat pada Bagan 1 berikut. 


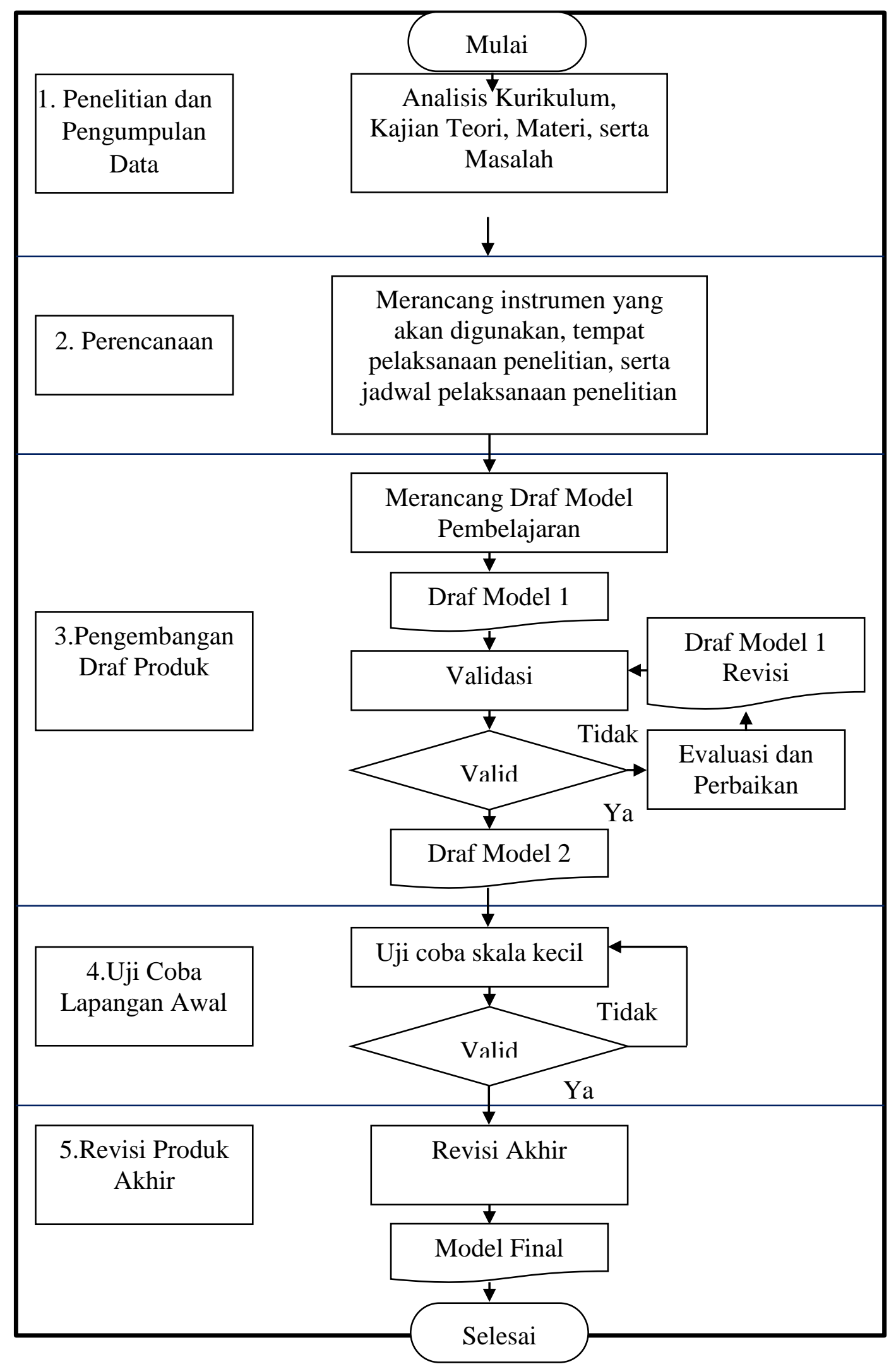

Bagan 1 Prosedur Penelitian dan Pengembangan (diadaptasi dari Model Borg \& Gall (Setyosari, 2015:292)) 


\section{HASIL}

Hasil pengembangan ini berupa model pembelajaran matematika STAIR (Study Confident in Pair) pada materi perbandingan untuk siswa kelas VII SMP/MTs yang merupakan kombinasi dari dua tipe model pembelajaran koopeartif dengan tujuan untuk meningkatkan aktivitas peserta didik selama proses pembelajaran. Materi pada pengembangan model pembelajaran ini disesuaikan dengan kurikulum 2013 SMP/MTs. Materi disusun sesuai dengan karakteristik model pembelajaran matematika STAIR (Study Confident in Pair).

Model pembelajaran matematika STAIR (Study Confident in Pair) ini membahas materi perbandingan tentang konsep perbandingan, perbandingan senilai, dan perbandingan berbalik nilai. Tahap pertama yang dilakukan adalah tahap penelitian dan pengumpulan data meliputi analisis kurikulum dan kajian teori pendukung, analisis materi, dan identifikasi masalah. Selanjutnya tahap perencanaan, yaitu merancang instrumen yang digunakan, menentukan tempat dan jadwal pelaksanaan penelitian. Pada tahap pengembangan draf produk dilakukan validasi draf awal kepada validator, yaitu validator ahli, praktisi dan user. Sedangkan tahap revisi akhir dilakukan revisi terhadap produk berdasarkan saran dari ahli, praktisi dan user. Model pembelajaran matematika STAIR (Study Confident in Pair) tersebut dituangkan ke dalam buku model. Adapun secara ringkas dapat dilihat pada gambar di bawah ini.

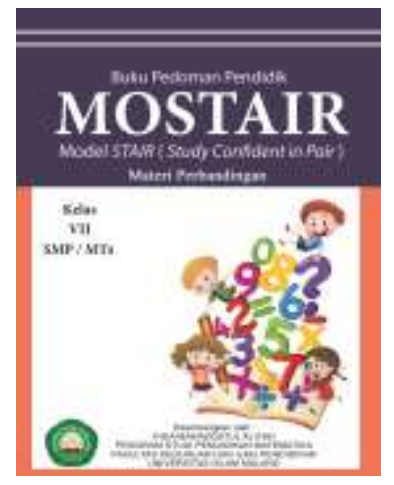

Gambar 1 Tampilan Buku Model

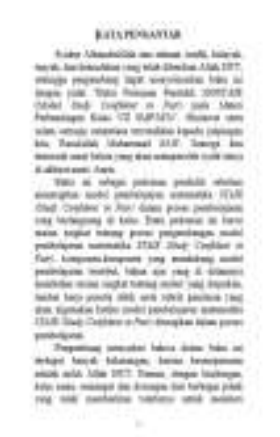

Gambar 2 Tampilan Halaman Pembuka

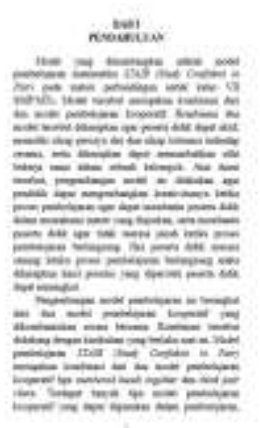

Gambar 3 Halaman Utama

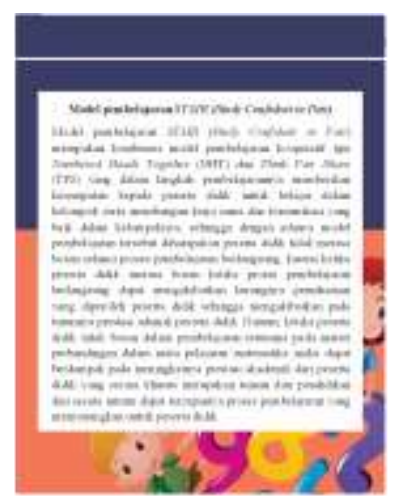

Gambar 4 Tampilan Cover sebagai Penutup

\section{Telaah Ahli}

Pada uji validasi model pembelajaran matematika STAIR (Study Confident in Pair), ada tiga validator dan dua user yaitu: validator ahli pembelajaran, ahli desain dan perancang pembelajaran, praktisi, pendidik, dan peserta didik. Berikut adalah hasil validasi ahli, praktisi, dan user. 
Tabel 1: Hasil validasi Ahli Pembelajaran

\begin{tabular}{|c|c|c|c|c|c|c|}
\hline No & Aspek & $\Sigma X_{I}$ & $n_{i}$ & $\frac{\sum X_{I}}{n_{i}}$ & $\mathrm{~S}$ & Kategori \\
\hline 1. & $\begin{array}{l}\text { Aspek kesesuaian model dengan } \\
\text { kebutuhan pembelajaran }\end{array}$ & 9 & 3 & 3,00 & 3,00 & Valid \\
\hline 2. & Aspek kejelasan model pembelajaran & 19 & 6 & 3,17 & 3,17 & Valid \\
\hline 3. & $\begin{array}{lll}\begin{array}{l}\text { Aspek kelengkapan } \\
\text { pembelajaran }\end{array} & \text { inti model } \\
\end{array}$ & 7 & 2 & 3,50 & 3,50 & Valid \\
\hline 4. & Aspek kegunaan model pembelajaran & 9 & 3 & 3,00 & 3,00 & Valid \\
\hline 5. & $\begin{array}{l}\text { Aspek kualitas rancangan hasil } \\
\text { pengembangan model pembelajaran }\end{array}$ & 11 & 3 & 3,67 & 3,67 & Valid \\
\hline 6. & Aspek bahasa dan penulisan & 11 & 3 & 3,67 & 3,67 & Valid \\
\hline & $\Sigma S_{I}$ & 20,01 & & & & \\
\hline $\mathrm{K}=$ & & 3,34 & & & & Valid \\
\hline
\end{tabular}

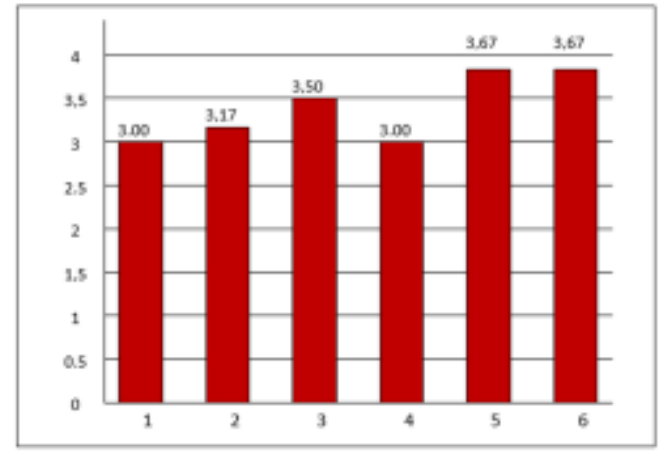

Grafik 1 Hasil Validasi Ahli Pembelajaran

Tabel 2: Hasil Validasi Ahli Desain dan Perancangan Pembelajaran

\begin{tabular}{|c|c|c|c|c|c|c|}
\hline No & Aspek & $\Sigma X_{I}$ & $n_{i}$ & $\frac{\Sigma X_{I}}{n_{i}}$ & $\mathrm{~S}$ & Kategori \\
\hline 1. & Format rencana pelaksanaan pembelajaran & 11 & 3 & 3,67 & 3,67 & Valid \\
\hline 2. & Isi rencana pelaksanaan pembelajaran & 19 & 5 & 3,80 & 3,80 & Valid \\
\hline 3. & Bahasa rencana pelaksanaan pembelajaran & 6 & 2 & 3,00 & 3,00 & Valid \\
\hline 4. & Format buku pedoman pendidik & 29 & 8 & 3,63 & 3,63 & Valid \\
\hline 5. & Kelayakan isi buku pedoman pendidik & 9 & 3 & 3,00 & 3,00 & Valid \\
\hline 6. & Penyajian isi buku pedoman pendidik & 9 & 3 & 3,00 & 3,00 & Valid \\
\hline 7. & Layout buku pedoman pendidik & 10 & 3 & 3,33 & 3,33 & Valid \\
\hline 8. & Bahasa dan penulisan buku pedoman pendidik & 6 & 2 & 3,00 & 3,00 & Valid \\
\hline 9. & Format bahan ajar & 30 & 8 & 3,75 & 3,75 & Valid \\
\hline 10. & Kelayakan isi bahan ajar & 9 & 3 & 3,00 & 3,00 & Valid \\
\hline 11. & Penyajian isi bahan ajar & 9 & 3 & 3,00 & 3,00 & Valid \\
\hline 12. & Layout bahan ajar & 9 & 3 & 3,00 & 3,00 & Valid \\
\hline 13. & Bahasa dan penulisan bahan ajar & 6 & 2 & 3,00 & 3,00 & Valid \\
\hline 14. & Isi rubrik penilaian pembelajaran & 8 & 2 & 4,00 & 4,00 & Valid \\
\hline 15. & $\begin{array}{l}\text { kelengkapan instrumen } \\
\text { pembelajaran }\end{array}$ & 4 & 1 & 4,00 & 4,00 & Valid \\
\hline 16. & Kriteria rubrik penilaian pembelajaran & 8 & 2 & 4,00 & 4,00 & Valid \\
\hline \multirow[t]{2}{*}{17.} & $\begin{array}{l}\text { Kebahasan dan penulisan rubrik penilaian } \\
\text { pembelajaran }\end{array}$ & 3 & 1 & 3,00 & 3,00 & Valid \\
\hline & $\Sigma S_{I}$ & 57,18 & & & & \\
\hline \multicolumn{2}{|c|}{$\mathrm{K}=\frac{\Sigma X_{I}}{n_{i}}$} & 3,36 & & & & Valid \\
\hline
\end{tabular}




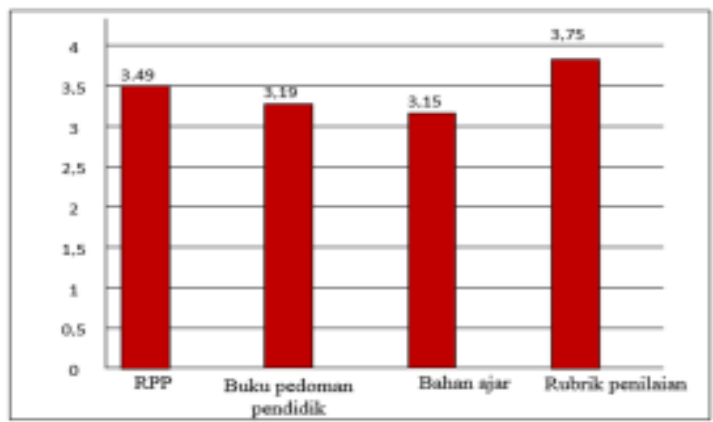

Grafik 2 Hasil Validasi Ahli Desain dan Perancang Pembelajaran

Tabel 3: Hasil Validasi Praktisi

\begin{tabular}{|c|c|c|c|c|c|c|}
\hline \multirow{2}{*}{\multicolumn{2}{|c|}{ Aspek }} & \multirow[t]{2}{*}{$\Sigma X_{I}$} & \multirow[t]{2}{*}{$n_{i}$} & $\sum X_{I}$ & \multirow[t]{2}{*}{$\mathrm{S}$} & \multirow[t]{2}{*}{ Kategori } \\
\hline & & & & $n_{i}$ & & \\
\hline 1. & Aspek kualitas rancangan buku model pembelajaran & 30 & 9 & 3,33 & 3,33 & Valid \\
\hline 2. & $\begin{array}{l}\text { Aspek kesesuaian model dengan kebutuhan } \\
\text { pembelajaran }\end{array}$ & 11 & 3 & 3,67 & 3,67 & Valid \\
\hline 3. & Aspek kelengkapan inti model pembelajaran & 10 & 3 & 3,33 & 3,33 & Valid \\
\hline 4. & Aspek nilai kegunaan model pembelajaran & 6 & 2 & 3,00 & 3,00 & Valid \\
\hline 5. & $\begin{array}{l}\text { Aspek format penyusunan komponen-komponen } \\
\text { model pembelajaran }\end{array}$ & 4 & 1 & 4,00 & 4,00 & Valid \\
\hline 6. & Aspek isi komponen model pembelajaran & 50 & 14 & 3,57 & 3,57 & Valid \\
\hline \multirow[t]{2}{*}{7.} & $\begin{array}{l}\text { Aspek nilai kegunaan instrumen penilaian model } \\
\text { pembelajaran }\end{array}$ & 29 & 8 & 3,63 & 3,63 & Valid \\
\hline & $\Sigma S_{I}$ & \multicolumn{2}{|c|}{24,53} & & & \\
\hline \multicolumn{2}{|c|}{$\mathrm{K}=\frac{\Sigma X_{I}}{n_{i}}$} & \multicolumn{2}{|c|}{3,50} & & & Valid \\
\hline
\end{tabular}

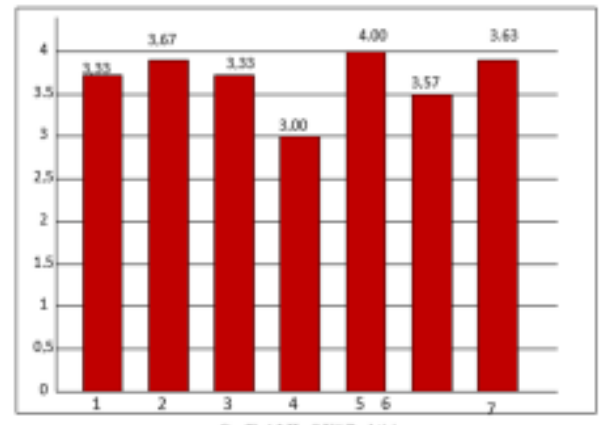

Grätîk 3 Hasil Validasi Praktisi

Tabel 4: Hasil Analisis data Kelompok Ahli dan Praktisi

\begin{tabular}{llll}
\hline No & Aspek & $\mathrm{K}$ & Keterangan \\
\hline 1. & Validator ahli pembelajaran matematika & 3,34 & Valid \\
\hline 2. & Validator ahli desain dan perancang pembelajaran & 3,36 & Valid \\
\hline 3. & Validator praktisi & 3,50 & Valid \\
\hline \multicolumn{2}{r}{$\quad \Sigma K_{I}$} & 10,2 & Valid \\
\hline \multicolumn{2}{l}{ Rata-rata total $(\mathrm{NK})=\frac{\Sigma K_{I}}{N}$} & 3,40 & Valid \\
\hline
\end{tabular}




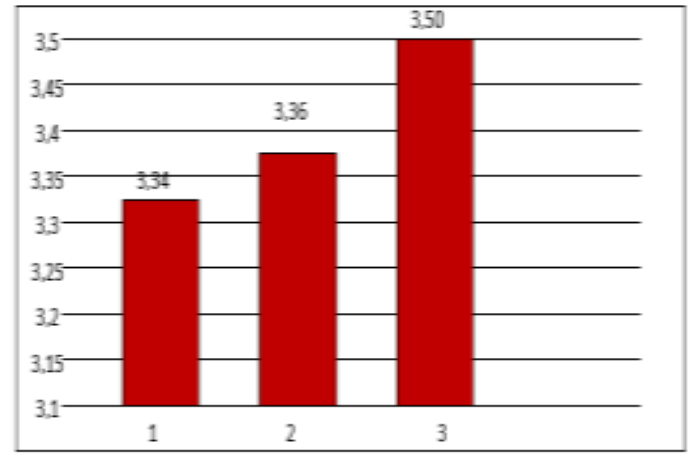

\section{Grafik 4 Hasil Analisi Data Kelompok Ahli dan Praktisi}

Dari Tabel 4 diperoleh nilai rata-rata total dari semua validator adalah 3,40, maka dapat ditarik kesimpulan bahwa pengembangan model pembelajaran matematika STAIR (Study Confident in Pair) pada materi perbandingan untuk siswa kelas VII SMP/MTs adalah valid. Selanjutnya dalam Grafik 4 juga telah disajikan tentang penilaian dari ketiga validator sehingga dapat diketahui skor masing-masing validator.

Setelah model pembelajaran matematika STAIR (Study Confident in Pair) melalui uji validasi, selanjutnya diterapkan dalam kelas dan untuk pengguna baik pendidik maupun peserta didik diberikan angket respon terhadap model pembelajaran yang telah diterapkan. Dibutuhkan seorang pendidik dan 9 peserta didik di MTs Al-Ma'arif Bocek Karangploso Malang kelas VII B untuk memberikan penilaian terhadap model pembelajaran yang telah diterapkan.

Tabel 5: Hasil Uji Coba User (Peserta Didik)

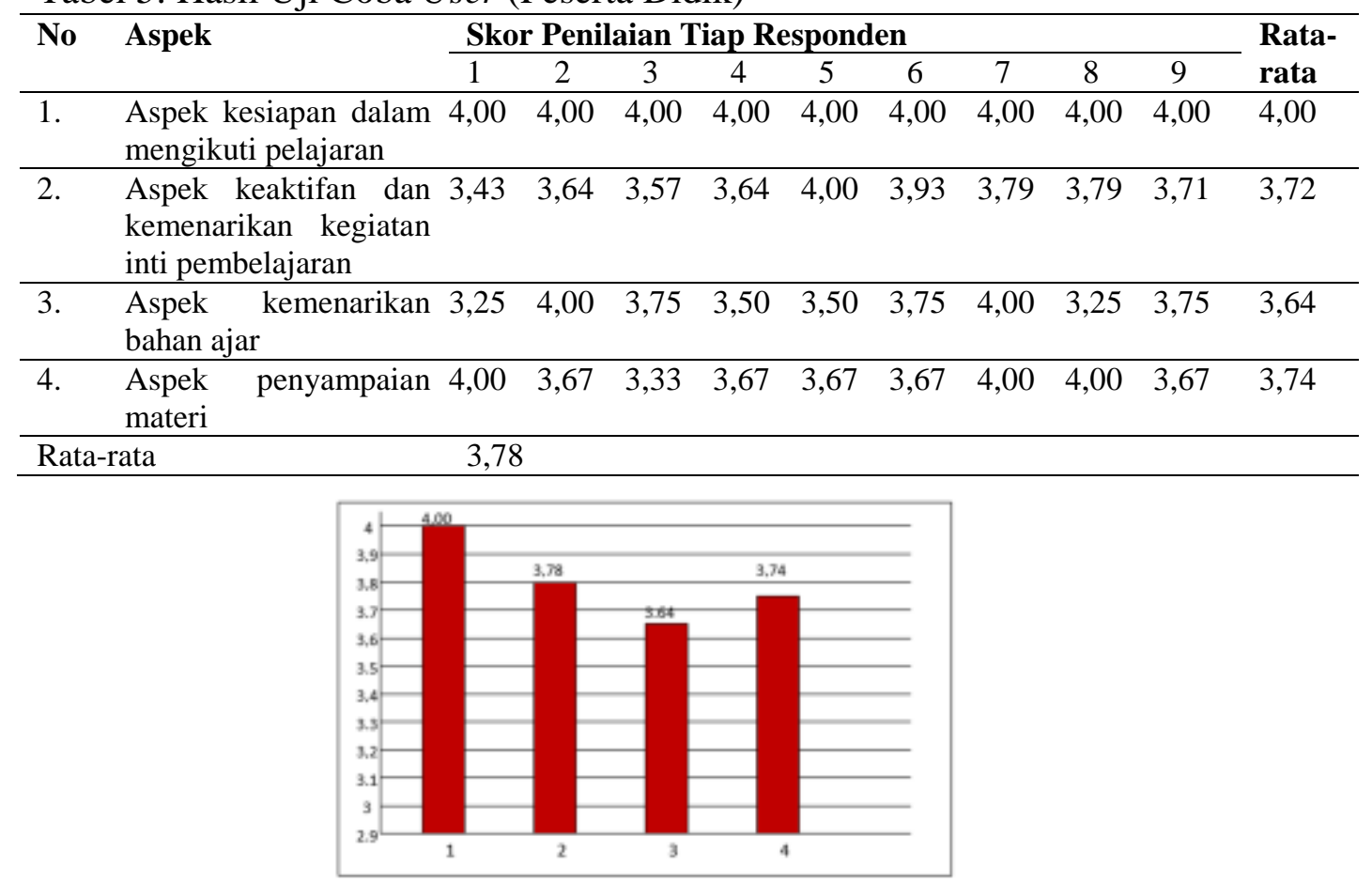

Grafik 5 Hasil Analisi Uji User (Peserta Didik)

Tabel 6: Hasil Uji Coba User (Pendidik) 


\begin{tabular}{cllll}
\hline No & Keterangan & $\Sigma X$ & $\mathrm{~N}$ & $\frac{\Sigma X_{I}}{N}$ \\
\hline 1. & Pernyataan tentang model pembelajaran yang dikembangkan & 55 & 16 & 3,44 \\
\hline \multicolumn{1}{c}{} & 3,44 & & \\
\hline
\end{tabular}

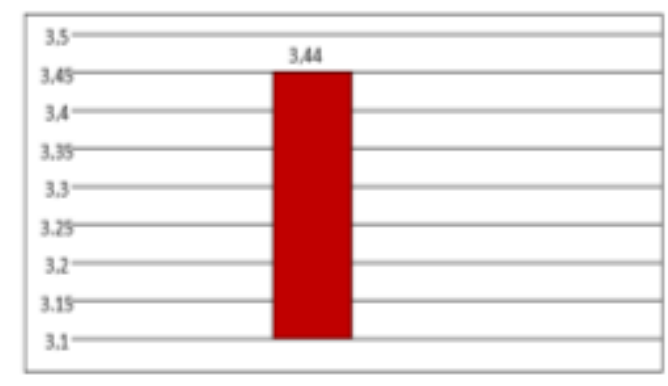

Grafik 6 Hasil Analisi Uji User (Pendidik)

Dari Tabel serta Grafik 5 dan 6 tersebut diperoleh skor 3,44 dari pendidik dan skor 3,78 dari peserta didik. Berdasarkan kriteria kepraktisan yang sudah dibahas sebelumnya maka skor dari pendidik dan peserta didik disimpulkan dalam kategori praktis.

\section{Tanggapan Peserta Didik dan Pendidik}

Dari hasil uji coba didapatkan tanggapan, kritik serta komentar dari peserta didik sebagai berikut: (1) Pendidik diharapkan bisa mengontrol peserta didik pada langkah mengkomunikasikan, (2) Pendidik diharapkan sering memantau peserta didik dalam diskusi agar suasana dapat terkendali, (3) Peserta didik yang tidak mendengarkan instruksi pendidik sebaiknya diberi peringatan atau ditunjuk untuk mengerjakan soal di depan kelas agar dia tidak mengulangi kesalahannya

\section{Revisi Produk}

Untuk mencapai produk yang mendekati sempurna dan memenuhi target ketepatan, kelayakan, dan kegunaan produk, maka model pembelajaran matematika untuk materi perbandingan ini melewati beberapa revisi sampai pada hasil akhir yang berupa media yang siap digunakan. Beberapa revisi yang dilakukan adalah sebagai berikut: (1) dalam kata pengantar ditambahkan penjelasan singkat tentang isi buku pedoman, 2) penulisan daftar isi perlu diperhatikan, dan 3) penulisan pada tabel perlu diperhatikan.

\section{PEMBAHASAN}

Penelitian ini membahas tentang pengembangan model pembelajaran matematika STAIR (Study Confident in Pair) pada materi perbandingan untuk siswa kelas VII SMP/MTs. Penelitian ini menggunakan penelitian pengembangan. Setyosari (2015:277) menyatakan bahwa pengembangan adalah suatu proses yang dipakai untuk mengembangkan dan memvalidasi produk pendidikan. Sedangkan Seels dan Richey (dalam Setyosari, 2015: 280) menyatakan bahwa pengembangan berarti proses menerjemahkan atau menjabarkan spesifikasi rancangan ke dalam bentuk fisik atau dengan ungkapan yang lain, pengembangan berarti proses menghasilkan bahan-bahan pembelajaran.

Dalam pengembangan ini, pengembang menggunakan lima tahapan yang diadaptasi dari model Borg \& Gall yaitu: penelitian dan pengumpulan informasi awal, perencanaan, pengembangan format produk, uji coba lapangan, dan revisi akhir. Pengembangan model tersebut divalidasi oleh validator dan dinilai kepraktisannya oleh user. Analisis data validasi oleh validator ahli dan praktisi masuk dalam kategori valid dan siap digunakan. Rinciannya adalah sebagai berikut: (a) validasi ahli pembelajaran matematika skor rata-ratanya adalah 3,34 masuk dalam kategori valid dan siap digunakan, (b) validasi ahli desain dan perancang 
pembelajaran dengan skor rata-ratanya adalah 3,36 masuk dalam kategori valid dan siap digunakan, (c) validasi praktisi dengan skor rata-rata 3,50.

Dari ketiga validator tersebut diperoleh skor kelompok validator yaitu 3,40 yang masuk dalam kategori valid dan siap digunakan. Penilaian kepraktisan dari uji user diperoleh skor rata-rata 3,44 untuk pendidik dan 3,78 untuk peserta didik, dengan demikian keduanya masuk dalam kategori sangat praktis. Hasil uji coba dari validasi ahli pembelajaran matematika, ahli desain dan perancang pembelajaran, praktisi, dan user diperoleh rata-rata skor sebesar 3,48 yang masuk dalam kategori valid dan praktis. Berdasarkan hasil yang diperoleh tersebut, maka pengembangan model pembelajaran yang dikembangkan pengembang dinyatakan valid dan siap digunakan.

\section{SIMPULAN DAN SARAN}

Produk dalam pengembangan ini adalah model pembelajaran matematika STAIR (Study Confident in Pair). Model tersebut berdasarkan kurikulum 2013 yang diterapkan untuk materi perbandingan. Adapun model pengembangan yang digunakan adalah model pengembangan yang diadaptasi dari model Borg \& Gall dengan lima tahapan yaitu: (1) penelitian dan pengumpulan data, (2) perencanaan, (3) pengembangan draft produk, (4) uji coba lapangan, dan (5) revisi akhir.

Dalam pengembangan model pembelajaran matematika STAIR (Study Confident in Pair) pada materi perbandingan untuk siswa kelas VII SMP/MTs diharapkan menjadi model pembelajaran yang dapat membatu untuk meningkatkan aktivitas peserta didik dan pemahaman materi bagi peserta didik.

\section{DAFTAR RUJUKAN}

Fathani, A. H. (2012). Matematika, Hakikat \& Logika. Yogyakarta: Ar-Ruzz Media.

Huda, M. (2013). Model-model pengajaran dan pembelajaran. Yogyakarta: Pustaka Belajar.

Hermindina, N. T. (2010). Penerapan Kolaborasi Model Numbered Heads Together dengan

Two Stay Two Stray untuk Meningkatkan Aktivitas dan Hasil Belajar Kewirausahaan

Siswa Kelas XII Jurusan Listrik SMK Negri 2 Probolinggo. Skripsi tidak diterbitkan.

Malang: Program S1 Universitas Negri Malang.

Sari, V. Y. (2013). Pengembangan Model Pembelajaran STADTUS (Kolaborasi STAD dengan Tutor Sebaya) dalam Pembelajaran IPA pada Siswa Kelas V di SDN Klojen Malang. Skripsi tidak diterbitkan. Malang: Program S1 Universitas Negri Malang.

Setyosari, P. (2015). Metode Penelitian Pendidikan dan Pengembangan. Jakarta: Prenada Media Group.

Suprijono, A. (2012). Cooperative Learning Teori dan Aplikasi Paikem. Yogyakarta: Pustaka Belajar. 